\title{
Research on chromium and arsenic speciation in atmospheric particulate matter: short review
}

\author{
Katarzyna Nocoń $^{1 *}$, Wioletta Rogula-Kozłowska ${ }^{1}$, and Kamila Widziewicz ${ }^{1}$ \\ ${ }^{1}$ Institute of Environmental Engineering Polish Academy of Sciences, 34 M. Skłodowskiej-Curie St., \\ 41-819 Zabrze, Poland
}

\begin{abstract}
Atmospheric particulate matter (PM) plays an important role in the distribution of elements in the environment. The PM-bound elements penetrates into the other elements of the environment, in two basic forms those dissolved in the atmospheric precipitation and those permanently bound to PM particles. Those forms differs greatly in their mobility, thus posing a potential threat to living organisms. They can also be an immediate threat, while being inhaled. Chromium (Cr) and arsenic (As) belong to the group of elements whose certain chemical states exhibit toxic properties, that is $\mathrm{Cr}(\mathrm{VI})$ and $\mathrm{As}(\mathrm{III})$. Thus, recognition of the actual threat posed by $\mathrm{Cr}$ and $\mathrm{As}$ in the environment, including those present in PM, is possible only through the in depth speciation analysis. Research on the $\mathrm{Cr}$ and As speciation in PM, more than the analogous studies of their presence in other compartments of the environment, have been undertaken quite rarely. Hence the knowledge on the speciation of PM-bound As and $\mathrm{Cr}$ is still limited. The state of knowledge in the field of PM-bound $\mathrm{Cr}$ and $\mathrm{As}$ is presented in the paper. The issues related to the characterization and occurrence of $\mathrm{Cr}$ and As species in PM, the share of $\mathrm{Cr}$ and As species mass in different PM size fractions, and in PM of different origin is also summarized. The analytical techniques used in the speciation analysis of $\mathrm{PM}$-bound $\mathrm{Cr}$ and $\mathrm{As}$ are also discussed. In the existing literature there is no data on the physical characteristics of $\mathrm{Cr}$ and As (bound to a different PM size fractions), and thus it still lack of data needed for a comprehensive assessment of the actual environmental and health threat posed by airborne Cr and As.
\end{abstract}

\section{Introduction}

Chromium (Cr) and arsenic (As) are two elements widely common in environment. They occur in different chemical forms, which in case of As are more differentiated. The circulation of chromium and arsenic in the environment mostly involve their biologically active forms, present in an ionic forms, and by definition bioavailable for living organisms. The impact of chromium and arsenic on human's health depends mostly on their oxidation state. It is documented that $\mathrm{Cr}$ (III) takes a part in the processes of the formation and transformation of lipids, glucose and proteins, while $\mathrm{Cr}(\mathrm{VI})$ form is a known human

\footnotetext{
** Corresponding author: katarzyna.nocon@ipis.zabrze.pl
} 
carcinogen, characterized by a high toxicity [1]. After inhalation $\mathrm{Cr}(\mathrm{VI})$ migrate easily into respiratory track, where it cross the cell membranes and is further transported into the bloodstream. Similarly to $\mathrm{Cr}$, also the toxicity of As is related to the different chemical forms and oxidation states in which it can be found. It is recognized, that the inorganic arsenic species are more toxic than the organic ones (except trivalent organoarsenicals), and that $\mathrm{As}(\mathrm{III})$ is more toxic than $\mathrm{As}(\mathrm{V})$. At the cellular level, As(III) interacts with proteins and enzymes, causing oxidative stress and ablation of DNA by its methylation [2].

Considering the fact of As and Cr toxicity it can be stated that understanding their speciation is more important, than knowing its total contents in the exact elements of the environment [3]. All over the world the quantitative assessment of As and $\mathrm{Cr}$ species in all elements of the environment such as water, soil, sediments, wastes, plants, particulate matter etc. is a huge challenge. While looking into scientific literature it appears that particulate matter is probably the least recognized among above mentioned.

Atmospheric particulate matter (PM), also referred as aerosol, represents mixture of solid, liquid, semi-volatile and volatile compounds. PM is very complex, regarding particle size and composition, as it may contain metals, metalloids, inorganic ions, organic compounds, black carbon and biogenic material (e.g. algae, pollen, bacteria or fungi) [4]. Airborne chromium (i.e. PM-bound $\mathrm{Cr}$ ) exists in two valence states $\mathrm{Cr}(\mathrm{III})$ and $\mathrm{Cr}(\mathrm{VI})$. Similarly arsenic exist in PM in two valence states As(III) and As(V), in inorganic and/or organometalloid forms. Five different species of As have been detected in PM so far: the two inorganic species arsenite (As(III)) and arsenate $(\mathrm{As}(\mathrm{V}))$ and the organoarsenic methylated forms of $\mathrm{As}(\mathrm{V})$, that is methylarsonate (MA), dimethylarsinate (DMA) and trimethylarsine oxide (TMAO) [5].

The occurrence of different oxidation states of PM-bound As and $\mathrm{Cr}$ is dependent on their origin. It has been estimated that approximately two thirds of the $\mathrm{Cr}$ and $\mathrm{As}$ emissions to the atmosphere is related to anthropogenic sources. The main industrial $\mathrm{Cr}$ sources are: ferrochrome metallurgy, brick manufacturing, plating, fuels combustion, waste incineration, the production of $\mathrm{Cr}$-containing chemicals, mainly chromates and dichromates, pigments, $\mathrm{Cr}$ trioxide and $\mathrm{Cr}$ salts. Arsenic sources include mainly metal smelting, fossil fuels combustion and pesticide use, therefore $60 \%$ of the global anthropogenically-generated atmospheric arsenic is attributable to copper smelting and coal combustion. Natural sources of $\mathrm{Cr}$ and As emission include volcanic eruptions and erosion of soils and rocks. As can also be released from low temperature volatilization of organoarsenic compounds, forest fires and sea spray [6-8].

The prevailing compounds of considered elements in PM are inorganic compounds of $\mathrm{As}(\mathrm{V})$ and $\mathrm{Cr}(\mathrm{III})$. $\mathrm{Cr}(\mathrm{VI})$ contribute from 3 to $8 \%$ of the total chromium emission into atmosphere and it's lifetime is relatively short 0.7-4.8 days [6,9]. The compounds of $\mathrm{Cr}$ and As in PM as well as the shares of its particular species are shaped by emission sources.

$\mathrm{X}$-ray analysis of $\mathrm{PM}$ collected in industrial area showed that arsenic is present as: $\mathrm{Ca}_{3} \mathrm{Sr}_{2}\left(\mathrm{AsO}_{4}\right) 2.5\left(\mathrm{PO}_{4}\right) 0.5(\mathrm{OH}), \mathrm{As}_{2} \mathrm{O}_{3}$ and $\mathrm{As}_{2} \mathrm{O}_{5}$ [10] and chromium is present in the chemical forms: $\mathrm{Cr}_{2} \mathrm{O}_{3}, \mathrm{Cr}-\mathrm{Fe}$ spinel, $\mathrm{Cr}(\mathrm{OH})_{3}, \mathrm{Cr}\left(\mathrm{NO}_{3}\right)_{3}, \mathrm{Cr}_{2}\left(\mathrm{SO}_{4}\right)_{3}$, and $\mathrm{CrCl}_{3}$. Most of them are not soluble in water in contrary to $\mathrm{Cr}(\mathrm{VI})$ compounds, which are water-soluble unless existing as $\mathrm{PbCrO}_{4}, \mathrm{BaCrO}_{4}$ and $\mathrm{ZnCrO}_{4}$ (emitted during utilization of chromate pigments and dyes). Soluble $\mathrm{Cr}(\mathrm{VI})$ is reported to be dominant in mobile and fuel combustion emission [11].

The source of PM emission also affects the mass shares of particles in specific size ranges (size fractions) and in the total PM mass. While most mining operations generate coarse PM, high temperature processes, such as smelting and coal combustion, are typically associated with fine PM. Coarse PM (particles with aerodynamic diameter $\geq 2.5 \mu \mathrm{m}$ ) are produced usually by mechanical processes such as crushing and grinding of ore and may be resuspended via wind erosion and mechanical disturbance. Fine PM (particles with 
aerodynamic diameter $\leq 2.5 \mu \mathrm{m}$ ) are produced during smelting and combustion through the condensation of high temperature vapors, diffusion and coagulation [12]. It is known that PM generated by anthropogenic sources consists mostly of fine particles, with the domination of particles below $1 \mu \mathrm{m}[13,14]$. Generally, it can be stated, that fine particles, mainly due to the chemical composition, are characterized by much greater surface area than coarse one. Many studies confirm connection between the size of the surface area, and the ability of PM particles to cumulate metals and metalloids. In the Polish urban areas, approximately $70-90 \%$ of total PM-bound metal mass is bound to submicron particles $\left(\mathrm{PM}_{1}\right)$ [15-17].

The aim of the paper is to synthetize the state of knowledge on the presence of chromium and arsenic species in atmospheric particulate matter available in the national literature including such information as: (i) characterization and occurrence of $\mathrm{Cr}$ and As species in PM, (ii) the mass share of $\mathrm{Cr}$ and As species in different PM size fractions and in PM of different origin, (iii) the analytical techniques used in the speciation analysis of PMbound $\mathrm{Cr}$ and As.

\section{Application of Chromium and Arsenic Speciation Analyses in PM Samples}

Among PM-bound elements in urban air, $\mathrm{Cr}$ and As are those, which can affect human health. The negative health effect, after exposure by inhalation of PM-bound $\mathrm{Cr}$ and As, depends mainly on their oxidation states, solubility of their compounds and their mass distribution respect to inhaled particles $[1,12]$. It is established that the smaller is the PM diameter, the higher its capacity to penetrate into the respiratory track: particles with aerodynamic diameter equal to $10 \mu \mathrm{m}$ can reach the larynx, $2.5 \mu \mathrm{m}$ the bronchi, and $1 \mu \mathrm{m}$ the alveoli [18]. For this reason interest in species-selective analysis especially of fine PM samples has increased in recent decades.

Research on $\mathrm{Cr}$ and As and their species show that the concentrations of their species in PM are spatially dependent and are mainly shaped by local emission. Higher concentration of PM-bound $\mathrm{Cr}$ and $\mathrm{As}$ and their species ( $\mathrm{Cr}(\mathrm{VI})$ and $\mathrm{As}(\mathrm{V})$ ) were determined in the regions where local emission is mainly industrial, in comparison to areas, where the influence of industry is not prevailing, or where the area is located far from the direct impact of the industrial source emission [19-24]. For example, in urban areas, close to chromium emission sources in particular, $\mathrm{Cr}(\mathrm{VI})$ concentration can achieve values, e.g. 20 $\mathrm{ng} / \mathrm{m}^{3}$ close to a foundry [19] and 20-70 $\mathrm{ng} / \mathrm{m}^{3}$ around a ferrochrome smelter [20]. Talebi [21] reported 5.4-8.2 ng/ $\mathrm{m}^{3}$ ambient concentration of PM-bound $\mathrm{Cr}$ (VI) in Isfahan (Iran), where two large iron and steel factories were located nearby. The $\mathrm{PM}_{10}$-bound $\mathrm{Cr}(\mathrm{VI})$ concentrations in Belgium were $5.2 \mathrm{ng} / \mathrm{m}^{3}$ close to stainless steel factory and $1.2 \mathrm{ng} / \mathrm{m}^{3}$ in location further away [22]. Świetlik et al. [23] determined Cr species in PM (TSP) collected in 4 locations characterized by domestic and vehicular emission and in one with an industrial emission (co-fired plants and metalworking plants) in Radom (Poland). The PM from industrial zone turned out to be almost fivefold richer in $\mathrm{Cr}$ (III). The level of $\mathrm{Cr}$ (VI) in air over the whole city was similar and the mean concentration of PM-bound $\mathrm{Cr}(\mathrm{VI})$ was $6.0 \mathrm{ng} / \mathrm{m}^{3}$. In non-polluted areas mean concentration of $\mathrm{Cr}(\mathrm{VI})$ was lower than $0.5 \mathrm{ng} / \mathrm{m}^{3}$ [24].

While examining the influence of industry on PM -bound As levels Oliveira et al. [25] found that close to the cooper smelter the contents of As species in TSP were $1.2 \mathrm{ng} \mathrm{m}^{-3}$ As(III) and $10.4 \mathrm{ng} \mathrm{m}^{-3} \mathrm{As}(\mathrm{V})$. In Taiwan in China the average concentrations of TSPbound arsenic species at industrial area (thermal power plant) were $1.06 \mathrm{ng} / \mathrm{m}^{3}$ and 2.49 $\mathrm{ng} / \mathrm{m}^{3}$ for $\mathrm{As}(\mathrm{III})$ and $\mathrm{As}(\mathrm{V})$, respectively; while in residential area they were $0.83 \mathrm{ng} / \mathrm{m}^{3}$ 
for $\mathrm{As}(\mathrm{III})$ and $1.96 \mathrm{ng} / \mathrm{m}^{3}$ for $\mathrm{As}(\mathrm{V})$ [26]. More examples of As species concentration from various mining operations are presented in review paper by Martin et al. [12].

Most of studies on $\mathrm{Cr}$ and As speciation in PM has been performed on total PM samples (so called total suspended particles, TSP) or either $\mathrm{PM}_{10}$ and $\mathrm{PM}_{2.5}$. Speciation of PMbound $\mathrm{Cr}$ and $\mathrm{As}$ in size-segregated samples has been studied only to a little extent. Inorganic arsenic species were determined for example in $\mathrm{PM}_{2.5-10}$ and $\mathrm{PM}_{2.5}$ in Tapada and Sines in Portugal [27], in $\mathrm{PM}_{10}$ and $\mathrm{PM}_{2.5}$ in Huelva in Spain [28], in Antwerp in Belgium [10] in $\mathrm{PM}_{2.5}$ and $\mathrm{PM}_{1}$ in Zabrze, Poland [29]. These studies indicate the presence of As(V) as the dominating specie in the PM samples, followed by As(III); only Tirez and coworkers [10] showed that the dominant specie in $\mathrm{PM}_{2.5}$ was As(III).

Chromium species was determined in $\mathrm{PM}_{2.5-10}$ and $\mathrm{PM}_{2.5}$ in Wielgegund, Southern Africa [30], in $\mathrm{PM}_{10}$ and $\mathrm{PM}_{2.5}$ in New Jersey, USA [31, 11], and in $\mathrm{PM}_{2.5}$ and $\mathrm{PM}_{1}$ in Zabrze, Poland [29]. In Africa the majority of $\mathrm{Cr}(\mathrm{VI})$ was found in $\mathrm{PM}_{2.5}$ [30]. This observation was explained by the nature of PM-bound $\mathrm{Cr}(\mathrm{VI})$ - emitted by pyrometallurgical plants in the studied region and the atmospheric lifetimes of different PM size fractions. Yu et al. and Huang et al. $[11,31]$ found that at the MERI site $(\sim 700 \mathrm{~m}$ from New Jersey Turnpike) concentrations of $\mathrm{PM}_{10}$-bound $\mathrm{Cr}(\mathrm{VI})$ were higher than concentrations of $\mathrm{PM}_{2.5}$-bound $\mathrm{Cr}(\mathrm{VI})$ both in summer and in winter. Widziewicz et al. [29] noticed higher concentrations of $\mathrm{PM}_{2.5}$-bound $\mathrm{Cr}(\mathrm{VI})$ than $\mathrm{PM}_{1}$-bound $\mathrm{Cr}(\mathrm{VI})$ only in summer. Generally, the higher concentration of $\mathrm{Cr}(\mathrm{VI})$ and higher ratio $\mathrm{Cr}(\mathrm{VI}) / \mathrm{Cr}(\mathrm{III})$ were observed in summer season compared to the winter season. Authors explained their findings by the fact, that the airborne $\mathrm{Cr}$ (III) can be oxidized to $\mathrm{Cr}(\mathrm{VI})$ by reactions with reactive oxygen species (ROS), characterized by strong oxidative capacity. Photoreactions are expected to be more intensive in the summer, also as a result of the presence of manganese in the ambient air [6]. Multiple linear regression analysis confirmed that the ambient concentrations of $\mathrm{Cr}(\mathrm{VI})$ were significantly affected by meteorological factors (i.e. temperature and humidity) and reactive gases particles (i.e. $\mathrm{O}_{3}, \mathrm{Fe}$ and $\mathrm{Mn}$ ) [31]. The mass distribution of $\mathrm{Cr}(\mathrm{VI})$ in respect to the particle size (8 PM fraction) was determined at the William site ( $\sim 50 \mathrm{~m}$ from New Jersey Turnpike) [31]. Authors found that greater mass of $\mathrm{Cr}(\mathrm{VI})$ was allocated in the size range below $2.5 \mu \mathrm{m}$ and the maximum of mass size distribution of $\mathrm{Cr}(\mathrm{VI})$ were found around the particle size of $2.5 \mu \mathrm{m}$. The results of $\mathrm{Cr}$ species masses distribution among 10 PM fractions from an industrial site in Northern Italy indicated that both mass concentration of $\mathrm{Cr}(\mathrm{VI})$ and $\mathrm{Cr}(\mathrm{VI}) / \mathrm{Cr}(\mathrm{III})$ ratio increase with the decrease in particle size [32]. The mass size distribution of $\mathrm{Cr}(\mathrm{VI})$ was unimodal and their maximum was in the range $0.56-1.0 \mu \mathrm{m}$. Mass size distribution of $\mathrm{Cr}(\mathrm{III})$, instead, was a bimodal with maxima in the ranges 1.0-1.8 and 5.6-10 $\mu \mathrm{m}$ [32]. The mass size distribution of $\mathrm{Cr}(\mathrm{III})$ is consistent with the distribution of total chromium in size-fractionated PM (13 PM fractions) collected in Zabrze (Poland) during winter [16, 17]. In Zabrze, Cr were accumulated mostly in fine particles and had bimodal mass size distribution with maxima in the ranges 1-1.6 and 6.8-10 $\mu \mathrm{m}$. Arsenic was accumulated mostly in submicron particles and had tetramodal distribution with maxima in the ranges $0.108-0.17 ; 0.4-0.65 ; 2.5-4.4$ and $6.8-10 \mu \mathrm{m}$. As speciation in size-segregated PM samples has not been found in literature. Therefore it seems reasonable to undertake further research on chromium and arsenic speciation in size-segregated PM.

\section{Sample preparation and analytical techniques for PM-bound $\mathrm{Cr}$ and As speciation}

Speciation of PM-bound $\mathrm{Cr}$ and As as an analytical process involves a few step, that are typically sampling, sample storage, sample pretreatment (extraction), separation of species 
and detection. Each of these steps of the procedural chain can influence the accuracy of determination of every specie of particular element, and each has to be optimized with respect to the other.

According to regulations referring to sampling of atmospheric air, PM can be collected on filters made of glass or quartz fiber filters, and cellulose or polycarbonate or PTFE (Teflon) membranes. The filters/membranes differ among each other for instance by flow resistant and so called "blank values" for determined element. Usually blank filters are initially prepared in order to minimize the analyte background ("blank values" in clean filters/membranes), i.e. minimize of positive artifacts in chemical analysis. The selection of the material of the filters is an important matter, because both filters and PM (deposited on filters) have to be digested or extracted with a suitable solution for posterior analysis of PM-bound $\mathrm{Cr}$ and As present. The desired extraction method must be therefore compatible with the analytical detection methods used and ideally require a small amount of PM sample. Since nineteen's a few methods using the alkaline digestion, for $\mathrm{Cr}(\mathrm{VI})$ determination in solid matrices, including atmospheric PM have been developed [32]. Among mentioned, standard methods dedicated for PM (ASTM, NIOSH and OSHA) differ on sample pretreatment level - filter material (PVC, quartz, Teflon), except ASTM, and/or extraction conditions $\left(\mathrm{NaOH}, \mathrm{Na}_{2} \mathrm{CO}_{3}, \mathrm{NaHCO}_{3}\right)$ but all are fallowed by Ion Chromatography and UV detection after DPC derivatization (Table 1). US EPA 3060A alkaline digestion method for determination of $\mathrm{Cr}(\mathrm{VI})$ in solid matrices was also used for PM samples [23, 29, 30]; its modified version was used by Huang et al. [11]. Chromium in extracts has been analyzed also by such techniques as: catalytic cathodic stripping voltammetry with adsorption of Cr(III)-DTPA complexes (CCSV-DTPA), graphite furnace atomic absorption spectroscopy (GF-AAS), inductively coupled plasma optical emission spectrometry (ICP-OES) (Table 1).

Over the past few years, two review papers have been published on the methodology used to determine the inorganic and organic species of arsenic in PM samples [34, 35]. Therefore in the presented work the authors focused only on the latest publications (Table1). As shown in Table 1 PM samples for arsenic species determinations were prepared by acid extraction/digestion with using solution such as: $\mathrm{HNO}_{3}, \mathrm{H}_{3} \mathrm{PO}_{4}$, $\mathrm{NH}_{2} \mathrm{OH} \cdot \mathrm{HCl}$, ascorbic acid or with citrate buffer. The latest trends in detection element species concern the so-called hyphenated techniques [36]. Determination of As species in PM has been performed with a very sensitive HPLC methodology coupled with hydride generation and atomic fluorescence spectrometry (HPLC-HG-AFS) or with inductively coupled plasma mass spectrometry (HPLC-ICP-MS).

The environmental conditions in which the extraction of analytical species is carried out are conducive to its transformation. Especially $\mathrm{Cr}(\mathrm{VI})$ is very reactive, and inter-conversion between $\mathrm{Cr}$ species can easily occur during sampling and sample processing. So very important in the speciation analyses is the optimization of the extraction procedure (time and conditions of ambient air), followed by compatible detection method, in order to minimize changes of analytes oxidation state. Because there is no CRM for $\mathrm{Cr}$ and As species in PM, accuracy of the method (including possible determined element species interconversion) can be evaluated mainly by recovery of known concentration of proper species standards added to PM sample. In case of Cr recovery of $\mathrm{Cr}$ (VI) both by external standard method from soil CRM and by speciated isotope-dilution mass spectrometry (SIDMS) method (EPA Method 680) from isotope Cr (VI) and Cr (III) enriched PM sample were studied [33, 38, 39]. SIDMS method occurred to be useful in correction of possible $\mathrm{Cr}$ species interconversion for determination of their soluble forms [11, 39]. 


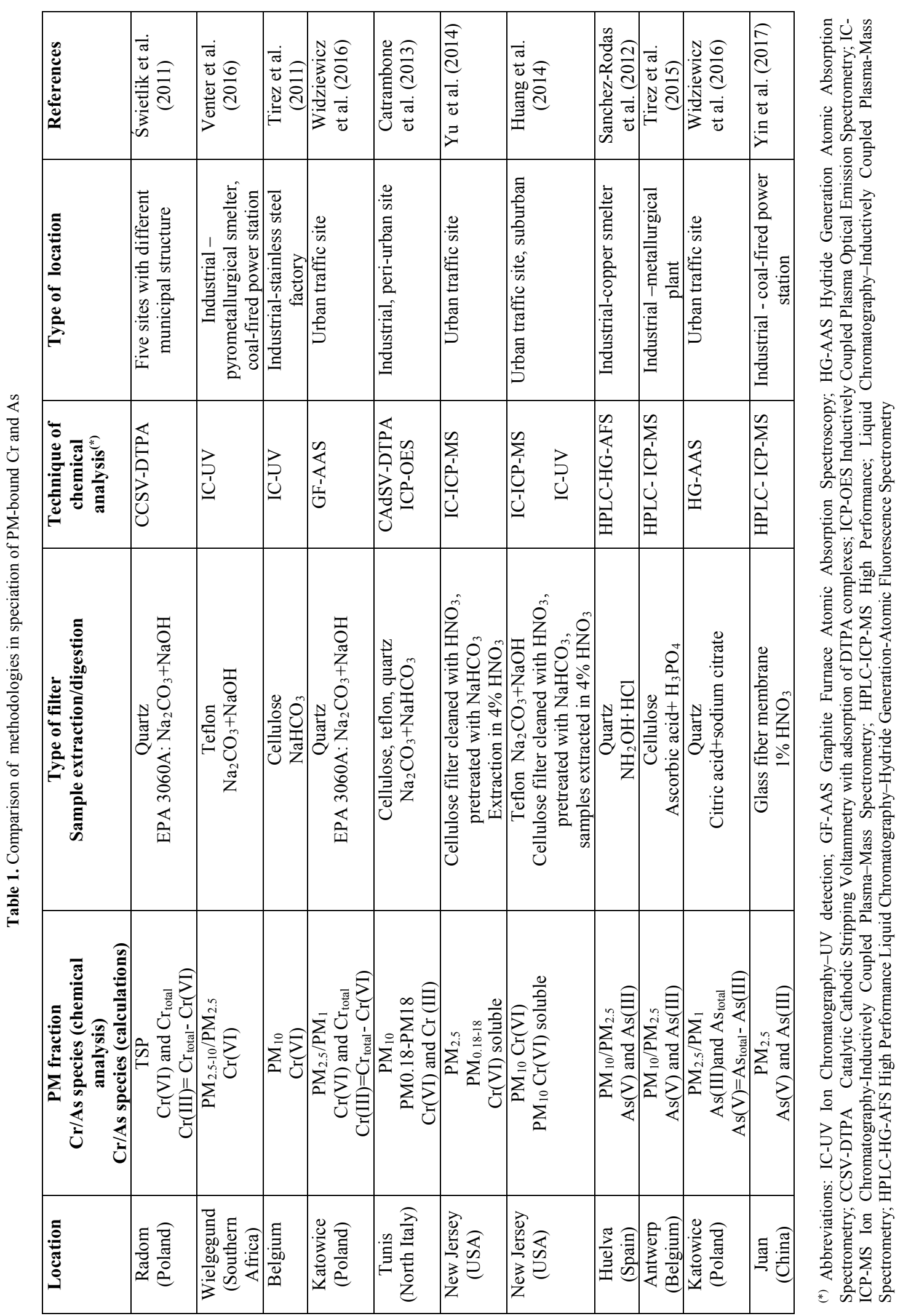




\section{Overall summary and conclusions}

Chemical speciation of toxic elements, such chromium and arsenic, in an environmental samples gives a crucial information on their amounts present in different oxidation form, that are characterized by different toxicity, availability, and reactivity. The share of toxic forms of airborne As and $\mathrm{Cr}$ in their total PM-bound mass is of great importance in environmental and human health effects. Most interesting seems to be the information on the contents of toxic forms of $\mathrm{Cr}$ and $\mathrm{As}$ in fine particulate matter, characterized by long residence time in atmosphere and free migration to the respiratory tract.

Till now the most research works on $\mathrm{Cr}$ and As speciation concern their presence in $\mathrm{PM}_{2.5}, \mathrm{PM}_{2.5-10}$ or $\mathrm{PM}_{10-40}$. There is a scarce research on chromium and arsenic speciation in ultrafine PM fraction and on the mass size distribution of their species in PM. Published results of research on mass size distribution of $\mathrm{Cr}$ in atmospheric air (two studies) indicate that their toxic specie - $\mathrm{Cr}(\mathrm{VI})$ tend to cumulate in fine $\mathrm{PM}_{2.5}$. Published results on As species in coarse and fine fraction (collected during the same research campaign) indicated that toxic As(III) was rather tend to cumulate in finer one.

It can be stated that in the present state of knowledge there is not enough data on PMbound $\mathrm{Cr}$ and As distribution within size-fractionated particles for a comprehensive assessment of the actual threat posed by atmospheric $\mathrm{Cr}$ and As. In connection with the above, it is still a challenge to describe the nature of $\mathrm{Cr}$ and As species distribution of in the function of the PM aerodynamic diameter in relation to all factors shaping the distribution.

The work was financed in the frame of project „Studies on the speciation of chromium and arsenic in size-fractionated urban aerosol" (UMO-2016/23/N/ST10/03032) by National Science Center, Poland $(\mathrm{NCN})$

\section{References}

1. IARC, IARC Monogr. Eval. Carcinog. Risks Hum. 49 (IARC Press, LYON, 2012)

2. K.T. Kitchin, K. Wallace J. Inorg. Biochem. 102, 8 (2008)

3. N. Unceta, F. Séby, J. Malherbe, O.F. Donard, Anal. Bioanal. Chem. 397, 15 (2010)

4. WHO, (Chapter 7.3 Copenhagen, Denmark, 2000b)

5. A. Jakob, K. Roth, K. Haas, E. M. Krupp, A. Raab, P. Smichowski, D. Gomez and J. Feldmann, J. Environ. Monit, 128 (2010)

6. C. Seigneur, E. Constantinou, Environ. Sci. Technol. 29, 10 (1995)

7. D. Kimbrough, Y. Cohen, A. Winer, L. Creelman, C. Mabuni, Crit. Rev. Environ Sci. Tech. 29, 47 (1999)

8. J. Matschullat, Sci. Total Environ. 249, 16 (2000)

9. WHO, (Chapter 6.1 Copenhagen, Denmark, 2000)

10. K. Tirez, C. Vanhoof, J. Peters, L. Geerts, N. Bleux, E. Adriaenssens, E. Roekens, S. Smolek, A. Maderitsch, R. Steininger, J. Goettlicher, F. Meirer, C. Streli, P. Berghmans, J. Anal. At. Spectrom. 30, 15 (2015)

11. L. Huang, C.H. Yu, P.K. Hopke, P.J. Lioy, B.T. Buckley, J.Y. Shin, Z.T. Fan Aerosol Air Qual Res. 14, 11 (2014)

12. H. R. Martin, K. Dowling, D. Pearce, J. Sillitoe, F. Singarayer, Geosci. 4, 48 (2014).

13. W. Birmili, A. G. Allen, F. Bary, R. M. Harrison, Environ. Sci. Technol. 40, 10 (2016) 
14. B. Chen, A. F. Stein, P. G. Maldonado, A. M. Sanchez de la Campa, M. GonzalezCastanedo, N. Castell, N. J. de la Rosa, Atmos. Environ. 71, 11 (2013)

15. W. Rogula - Kozlowska, B. Błaszczak, K. Klejnowski, Arch. of Environ. Prot. 37, 2, 9 (2011)

16. W. Rogula-Kozłowska, G. Majewski, P. Czechowski, Environ Monit Assess. 187, 240 (2015)

17. W. Rogula-Kozłowska, Air Qual. Atmos. Health. 9, 18 (2016)

18. J. S. Brown, T. Gordon, O. Price, B. Asgharian, Part. Fibre Toxicol. 10, 12 (2013)

19. P. Krystek, R. Ritsema, Int. J. Mass Spectrom. 265, 7 (2007)

20. K. L. Mandiwana, N. Panichev' T. Resane, J. Hazard. Mater. 136, 4 (2006)

21. S.M. Talebi, Environ. Res. 92,3 (2003)

22. K. Tirez, G. Silversmit, N. Bleux, E. Adriaensens, E. Roekens, K. Servaes, C. Vanhoof, L. Vincze, P. Berghmans, Atmos. Environ. 45, 10 (2011)

23. R Świetlik, A. Molik, M. Molenda, M. Trojanowska, J. Siwiec, Atmos. Environ. 45, 5 (2011)

24. J.H Seinfeld, S.N Pandis, Atmospheric Chemistry and Physics - From Air Pollution to Climate Change. (John Wiley \& Sons, 2006).

25. V. Oliveira, J.L. Gómez-Ariza, D. Sánchez-Rodas, Anal Bioanal Chem, 382, 6 (2005)

26. G.Ch. Fang, Ch.S. Huang, Ch.Y. Chang, J.H. Huang, Ch.K. Liu, Y. J. Zhuang, Y.F. Xiao, Y.Ch. Kuo, Ch. Y. Huang, K.H. Tsai, Environ. Earth Sci. 75, 124 (2016)

27. M.M. Farinha, Z. Slejkovec, J.T. van Elteren, H.T. Wolterbeck, M.C. Freitas, J. Atmos. Chem. 4911 (2004)

28. D. Sanchez-Rodas, A.S. de la Campa, V. Oliveira, J. de la Rosa, Atmos. Environ. 42(26) 11 (2012)

29. K. Widziewicz, W. Rogula - Kozlowska, K. Loska, Atmos. Pollut. Res. 7, 11 (2016)

30. A. D Venter, P. Beukes, P. Gideon van Zyl, M. Josipovic, K. Jaars, V. Vakkari, Atmos. Pollut. Res. 7, 6 (2016)

31. C.H. Yu, L. Huang, J.Y. Shin, F. Artigas, Z.T. Fan, Atmos. Environ. 94, 8 (2014)

32. M. Catrambone, S. Canepari, C. Perrino, E3S Web of Conferences 1 (2013), 10.1051/e3sconf/20130107005

33. R.E. Wolf, S.A. Wilson, Open-File Report 2010-1243 (U.S. Geological Survey, Reston, Virginia 2010)

34. A.S. Lewis, K. R. Reid, M. C. Pollock, S. L. Campleman, J Air Waste Manag Assoc. 62,1, 16 (2012)

35. D. Sanchez-Rodas, A.M. de la Campa, 1. Alsioufi, Anal. Chim. Acta. 898, 18 (2015)

36. R. Michalski, S. Szopa, M. Jabłońska, A. Łyko, Sci. World J. 2012, 17 (2012)

37. X. Yin, L. Wang, X. Yu, S. Du, H. Zhang, Z. Zhang, Pol. J. Environ. 26, 6 (2017)

38. Q. Meng, Z. Fan, B. Buckley, L. Lin, L. Huang, C-H. Yu, R. Stiles, L. Bonanno, Atmosph. Environ. 45, 7 (2011)

39. L. Huang, C-H. Yu, P. K. Hopke, J. Y. Shin, Z. Fan, J. Air Waste Manag. Assoc. 64, 7 (2014) 